\title{
Carbonaceous species in atmospheric aerosols from the Krakow area (Malopolska District): carbonaceous species dry deposition analysis
}

\author{
Katarzyna Szramowiat ${ }^{1}$, Katarzyna Styszko ${ }^{1, a}$, Magdalena Kistler ${ }^{2}$, Anne Kasper-Giebl² and Janusz Gołaś ${ }^{1}$ \\ ${ }^{1}$ AGH University of Science and Technology, Faculty of Energy and Fuels, Department of Coal Chemistry and Environmental Sciences, Av. \\ Mickiewicza 30, 30-059 Krakow \\ ${ }^{2}$ Institute of Chemical Technologies and Analytics, Vienna University of Technology, Getreidemarkt 9//164, Vienna, A-1060, Austria
}

\begin{abstract}
Organic and elemental carbon content in PM10 was studied at three sites in Malopolska District representing the city centre (Krakow), rural/residential (Bialka) and residential/industrial environments (Krakow). The PM10 samples were collected during the winter time study. The highest concentrations of carbonaceous species were observed in Skawina $\left(36.9 \mu \mathrm{g} \cdot \mathrm{m}^{-3}\right.$ of OC and $9.6 \mu \mathrm{g} \cdot \mathrm{m}^{-3}$ of EC). The lowest OC and EC concentrations were reported in Krakow $\left(15.2 \mu \mathrm{g} \cdot \mathrm{m}^{-3}\right.$ and $3.9 \mu \mathrm{g} \cdot \mathrm{m}^{-3}$, respectively. The highest concentration of carbonaceous species and the highest wind velocities in Skawina influenced the highest values of the dry deposition fluxes. Correlations between OC, EC and chemical constituents and meteorological parameters suggest that a) Krakow was influenced by local emission sources and temperature inversion occurrence; b) Bialka was under the influence of local emission sources and long-range transport of particles; c) Skawina was impacted by local emission sources.
\end{abstract}

\section{Introduction}

In recent years, scientists have taken a greater interest in atmospheric aerosols. This is especially due to the adverse impact of particulate matter on human health and due to the climate changes caused by aerosols. Unlike the gases present in the atmosphere, aerosols have a complex structure, and are composed of a wide range of both organic and inorganic chemical compounds. Aerodynamic diameter sizes range from several nanometres to several micrometres. The chemical composition is determined depending on the emission sources and meteorological conditions in the monitored region [1]. Through parameters such as solar radiation, temperature and relative humidity, air pollutants undergo several transformations and chemical reactions. Secondary pollutants, like ammonia sulphates and nitrates as well as organic acids, which are the constituents of the particulate matter, are the products of gas to particle conversion. These chemicals are the result of reactions with gas precursors like $\mathrm{SO}_{2}, \mathrm{NO}_{\mathrm{x}}$, $\mathrm{NH}_{3}$ or volatile organic compounds [2]. Coarse fraction particles in aerodynamic diameter from 2.5 to $10 \mu \mathrm{m}$, are constituted mostly of mineral components, like aluminium silicates, and other metals and non-metals [3]. The carbonaceous species (organic and elemental carbon) concentration contributes to $30-40 \%$ of the total mass of the coarse fraction. Elemental carbon (EC) is a primary pollutant, directly generated during the incomplete processes of fuel combustion, mainly diesel oil $[4,5]$. Thus, EC is frequently considered as a tracer for pollutants emitted from transportation [6,7]. Organic

\footnotetext{
a Corresponding author: styszko@agh.edu.pl
}

carbon (OC) is either, as in the case of EC, directly emitted during combustion processes (creating primary organic aerosols), or produced during the chemical reactions with gas precursors in the atmosphere creating secondary organic aerosols $[8,9]$.

Due to the increasing threat of high concentrations of particulate matter, the European Commission set up directives regulating the limits of aerosols in the atmosphere. Thus, in accordance with the 2008/50/EC directive, the daily and annual limits for PM10 are equal to $50 \mu \mathrm{g} / \mathrm{m}^{3}$ and $40 \mu \mathrm{g} / \mathrm{m}^{3}$, respectively. Krakow, like several other cities from the Malopolska District, is highly threatened by the accumulation of air pollution mainly because of the topography of the city and the presence of local emission sources. Krakow is located in a basin and is surrounded by high buildings, which block the natural ventilation of the city.

The aim of the study was to measure the PM10 concentration in the air at three different study locations of the Krakow agglomeration and to determine the contribution of elemental and organic carbon into the PM10 mass. The carbonaceous species dry deposition fluxes were also computed for the purpose of the study.

\section{Experimental part}

\subsection{Sampling}

Samples collection of the PM10 fraction was performed using a low volume sampler equipped with a $1 \mathrm{~kW}$ pump, a flow meter and a PM10 impactor by Digitel ${ }^{\circledR}$. The air flow was regulated to the constant value of $1 \mathrm{~m}^{3} \cdot \mathrm{h}^{-1}$. Particulate matter samples were collected on quartz fiber 
filters by Pallflex ${ }^{\circledR}$ with a diameter of $47 \mathrm{~mm}$. Prior to sampling, filters were pre-heated at $550{ }^{\circ} \mathrm{C}$ over $5 \mathrm{~h}$ and, afterwards, conditioned at a relative humidity of $50 \pm 5 \%$ at $20 \pm 2{ }^{\circ} \mathrm{C}$ over $24 \mathrm{~h}$. Sampling was carried out in accordance with regulations PN-EN 1234:1. In Krakow on weekdays the filters were changed in $24 \pm 2$ $\mathrm{h}$ intervals, while during weekends (Friday, Saturday and Sunday) the filters remained in samplers for around 70 hours. In Skawina and Bialka, filters were changed every 24 hours. Sampled filters were conditioned for 24 hours to achieve a constant humidity prior to weighting. The mass of the particulate matter was obtained as an average of three following weightings of the filter. The OHAUS Discovery DV215CD balance with a accuracy of $\pm 0,01 \mathrm{mg}$ was used for weighting. Detailed data on measurement locations are presented in Table 1.

PM10 samples were collected at three different measurement locations in the Malopolska District: in Krakow, Bialka and Skawina, representing three different types of the environment: city centre, rural/residential area and industrial/residential area, respectively. Krakow is the second-largest city in Poland by population and is inhabited by ca. 760 thousand inhabitants. It is located in the north part of the
Malopolska District. Krakow is inconveniently located in a basin, thus the natural ventilation of the city is blocked by the surrounding high buildings. As a result, pollution accumulates over the whole city. In Krakow, samples of PM10 were collected in the Krowodrza District, ca. $1 \mathrm{~km}$ from the main street characterized by a high intensity of traffic. Air aspirators were placed on the roof of a three-story building, at the height of ca. 10 $\mathrm{m}$.

Skawina is a medium-sized city, inhabited by ca. 25000 inhabitants. The city belongs to the industrial part of the Krakow agglomeration and is located ca. $15 \mathrm{~km}$ from the Krakow city centre. In Skawina, samplers were placed on the roof of a one-family house, at the height of ca. $5 \mathrm{~m}$, in the residential/industrial part of the city.

Bialka, a small village with 2000 inhabitants, is located ca. $60 \mathrm{~km}$ from Krakow, in the south-east part of the Malopolska District. Bialka is a typical rural/residential area, where almost $90 \%$ of households are heated by coal, frequently of a low quality, or by wood (in the authors' own estimation). Samplers were placed in a garden at the height of $2 \mathrm{~m}$, near the main street.

Table 1. Thorough data on study areas.

\begin{tabular}{|l|c|c|c|}
\hline & Krakow & Bial ka & Skawina \\
\hline Study period & $05-27.02 .2013$ & $02-16.03 .2013$ & $28.12 .2013-10.01 .2014$ \\
\hline Geographic coordinates & $\begin{array}{c}50^{\circ} 04^{\prime} 01.91^{\prime \prime} \mathrm{N} 19^{\circ} 54^{\prime} 45.60^{\prime \prime} \\
\mathrm{E}\end{array}$ & $\begin{array}{c}49^{\circ} 42^{\prime} 35.80^{\prime \prime} \mathrm{N} 19^{\circ} 41^{\prime} 10.32^{\prime \prime} \\
\mathrm{E}\end{array}$ & $\begin{array}{c}49^{\circ} 59^{\prime} 00.61^{\prime \prime} \mathrm{N} 19^{\circ} 50^{\prime} 07.61^{\prime \prime} \\
\mathrm{E}\end{array}$ \\
\hline Location type & City centre & $\begin{array}{c}\text { Rural/residential area } \\
\text { Industrial/residential area }\end{array}$ \\
\hline Filter type applied & $\begin{array}{c}\text { Tissuquartz Filters PallFlex }{ }^{\circledR}, \\
\varphi 47 \mathrm{~mm}\end{array}$ & $\begin{array}{c}\text { Tissuquartz Filters PallFlex }{ }^{\circledR}, \\
\varphi 47 \mathrm{~mm}\end{array}$ & $\begin{array}{c}\text { Tissuquartz Filters PallFlex }{ }^{\circledR}, \\
\varphi 47 \mathrm{~mm}\end{array}$ \\
\hline Filter changes intervals & $\begin{array}{c}24 \mathrm{~h} \text { (Monday - Thursday) } \\
72 \mathrm{~h} \text { (Friday - Sunday) }\end{array}$ & $24 \mathrm{~h}$ & $24 \mathrm{~h}$ \\
\hline
\end{tabular}

\subsection{Determination of PM10 chemical composition}

The concentration of organic and elemental carbon was determined using the thermal-optical method for OC/EC analysis (OC/EC analyzer by Sunset Laboratory Inc.), developed for atmospheric samples [6]. The Quartz.par protocol and laser transmittance methods were applied during measurements. $10 \mathrm{~mm}$ circle punches of quartz fiber filters with dust were analyzed without pretreatment of samples prior to analysis. The concentration of TC, OC and EC was automatically calculated on the base of the flow of the calibration gas $\left(\mathrm{He}+\mathrm{CH}_{4}\right.$, Air Liquid, Austria). The detection limits of TC, OC and EC were equal to $0.32 \mu \mathrm{g} \cdot \mathrm{m}^{-3}, 0.32 \mu \mathrm{g} \cdot \mathrm{m}^{-3}$, and $0.01 \mu \mathrm{g} \cdot \mathrm{m}^{-3}$, respectively. The repeatability of results was regularly controlled on the basis of the determination of carbonaceous species in the solution of sucrose containing $200 \mu \mathrm{g}$ of carbon in $20 \mu \mathrm{l}$ of solution. The relative standard deviation was equal to $3 \%$.

Within the presented study the concentration of the following inorganic ions: $\mathrm{Na}^{+}, \mathrm{K}^{+}, \mathrm{Mg}^{2+}, \mathrm{Ca}^{2+}, \mathrm{NH}_{4}^{+}$, $\mathrm{NO}_{3}^{-}, \mathrm{Cl}^{-}, \mathrm{SO}_{4}^{2-}$ was determined using the method of isocratic ion chromatography. Two $10 \mathrm{~mm}$ circle punches were extracted in $2 \mathrm{ml}$ of deionized water (MilliQplus 185, Millipore, 18.2 M $\Omega$ ) for anions concentration determination and in $3 \mathrm{ml}$ of $12 \mathrm{nM}$ methanesulfonic acid (MSA) for cations concentration determination. The extraction was carried out for $20 \mathrm{~min}$ in an ultrasonication bath. The DX-3000 (Thermo Scientific) ion chromatograph equipped with ionexchange column (anions: Ion Pac AS17A, mobile phase: $1.8 \mathrm{mM} \mathrm{Na} \mathrm{CO}_{3}+1.7 \mathrm{mM} \mathrm{NaHCO} 3$; cations: Ion Pac CS12A, mobile phase: $12 \mathrm{mM}$ MSA) was used in the study. After electrochemical suppression of eluent, analyte concentration was determined using the conductivity detector. Calibration of the method was based on the determination of the concentration of analytes in previously prepared external standard solutions (Merck). Detection limits (obtained multiplying the standard deviation calculated for blank solutions by a constant factor of 3.0) were equal to: $0.1 \mu \mathrm{g} \cdot \mathrm{m}^{-3}$ for $\mathrm{Na}^{+}$ and $\mathrm{Cl}^{-}$and $0.01 \mu \mathrm{g} \cdot \mathrm{m}^{-3}$ for the rest of the ions.

\subsection{Meteorological data}

The meteorological data (air temperature, wind speed, wind direction, humidity and precipitation volume) of atmospheric conditions in Krakow were downloaded from the online platform (http://meteo.ftj.agh.edu.pl/) where the results of the meteorological measurements are directly transferred from the Vaisala WXT520 automatic meteorological station. The station was placed on the roof 
of the building where the samples were collected. The meteorological data in Bialka and Skawina were downloaded from the online platforms www.meteoprog.pl and www.freemeteo.com. Table 2 includes the meteorological data recorded during the study periods. In order to compute the backward trajectory of air masses, the HYSPLIT (Hybrid Single-
Particle Lagrangian Integrated Trajectory) model was used: (http://ready.arl.noaa.gov/HYSPLIT traj.php [10]). The backward trajectories for the heating season sampling periods for Krakow, Bialka and Skawina were calculated basing on the following parameters: height of computation - 20,500 and 1500 m a.s.1.; trajectory duration $-72 \mathrm{~h}$.

Table 2. Summary of chemical composition of aerosols collected in Krakow, Bialka and Skawina and the meteorological parameters for study periods.

\begin{tabular}{|l|c|c|c|}
\hline Parameter & Krakow & Bial ka & Skawina \\
\hline $\mathrm{PM} 10\left[\mu \mathrm{g} \cdot \mathrm{m}^{-3}\right]$ & $60.3(36.5-128.4)$ & $87.4(60.4-111.6)$ & $62.8(30.1-117.1)$ \\
$\mathrm{EC}\left[\mu \mathrm{g} \cdot \mathrm{m}^{-3}\right]$ & $3.9(1.4-11.7)$ & $4.1(1.5-9.9)$ & $9.6(5.2-15.7)$ \\
$\mathrm{OC}\left[\mu \mathrm{g} \cdot \mathrm{m}^{-3}\right]$ & $15.2(7.3-35.0)$ & $20.8(7.4-31.8)$ & $36.9(13.2-74.8)$ \\
$\mathrm{Cl}-\left[\mu \mathrm{g} \cdot \mathrm{m}^{-3}\right]$ & $1.5(0.4-5.1)$ & $0.9(0.1-2.2)$ & $3.7(<\mathrm{LOD}-9.2)$ \\
$\mathrm{NO}^{-}\left[\mu \mathrm{g} \cdot \mathrm{m}^{-3}\right]$ & $3.6(0.8-6.5)$ & $2.2(1.3-4.3)$ & $2.3(<\mathrm{LOD}-4.2)$ \\
$\mathrm{SO}_{4}{ }^{2-}\left[\mu \mathrm{g}^{-3} \mathrm{~m}^{-3}\right]$ & $6.3(1.4-12.6)$ & $7.6(3.3-16.0)$ & $3.1(0.02-6.5)$ \\
$\mathrm{Na}^{+}\left[\mu \mathrm{g} \cdot \mathrm{m}^{-3}\right]$ & $0.3(0.1-0.5)$ & $0.3(0.1-0.9)$ & $0.4(0.2-0.7)$ \\
$\mathrm{NH}_{4}\left[\mu \mathrm{g}^{-3} \mathrm{~m}^{-3}\right]$ & $3.8(1.4-7.3)$ & $3.4(1.8-6.2)$ & $3.5(2.0-5.8)$ \\
$\mathrm{K}^{+}\left[\mu \mathrm{g} \cdot \mathrm{m}^{-3}\right]$ & $0.2(0.1-0.5)$ & $0.4(0.1-0.8)$ & $0.6(0.3-1.3)$ \\
$\mathrm{Mg}^{2+}\left[\mu \mathrm{g} \cdot \mathrm{m}^{-3}\right]$ & $0.01(<\mathrm{LOD}-0.05)$ & $0.01(<\mathrm{LOD}-0.06)$ & $0.03(0.01-0.10)$ \\
$\mathrm{Ca}{ }^{2+}\left[\mu \mathrm{g} \cdot \mathrm{m}^{-3}\right]$ & $0.1(0.02-0.5)$ & $0.05(<\mathrm{LOD}-0.6)$ & $0.2(0.1-0.3)$ \\
$\mathrm{EC} / \mathrm{PM} 10[-]$ & $0.06(0.03-0.1)$ & $0.05(0.02-0.1)$ & $0.2(0.1-0.5)$ \\
$\mathrm{OC} / \mathrm{EC}[-]$ & $4.6(2.2-7.8)$ & $6.4(2.8-10.9)$ & $4.0(0.8-6.7)$ \\
\hline Temperature $\left[{ }^{\circ} \mathrm{C}\right]$ & $0.4(-2.8-4.5)$ & $-0.3(-6.4-5.9)$ & $2.3(-5.0-7.0)$ \\
$\mathrm{Relative} \mathrm{humidity}[\%]$ & $76(68-84)$ & $84(56-99)$ & $94(80-100)$ \\
Wind velocity $\left[\mathrm{m} \cdot \mathrm{s}^{-1}\right]$ & $1.7(0.7-2.5)$ & $1.4(0-3.1)$ & $5.3(1.0-14.0)$ \\
\hline
\end{tabular}

\section{Results and discussion}

\subsection{PM10 concentrations at measuring locations}

Average concentrations of chemical constituents of PM10 obtained within analytical measurements of particulate matter samples from Krakow, Bialka and Skawina are summarized in Table 2. The daily accepted value of PM10 $\left(50 \mu \mathrm{g} \cdot \mathrm{m}^{-3}\right)$ was exceeded several times during all study periods in Krakow ( 8 exceedances) and Skawina (7 exceedances), whereas in Bialka extremely high concentrations of PM10 were reported for the whole study period resulting in the average value of PM10 equal to $87.4 \mu \mathrm{g} \cdot \mathrm{m}^{-3}$ and ranged from 60.4 to $111.6 \mu \mathrm{g} \cdot \mathrm{m}^{-3}$. The mean concentration of PM10 in Krakow was accounted for $60.3 \mu \mathrm{g} \cdot \mathrm{m}^{-3}$ ranging between 36.5 and $128.4 \mu \mathrm{g} \cdot \mathrm{m}^{-3}$. Occurrence of PM10 particles in Skawina was reported on the average level of $62.8 \mu \mathrm{g} \cdot \mathrm{m}^{-3}$ ranging between 30.1 and $117.1 \mu \mathrm{g} \cdot \mathrm{m}^{-3}$ (Table 2).

Figure 1 presents the variations of the PM10 concentration measured for Krakow, Bialka and Skawina during the study periods against the relative humidity and ambient temperature. In these plots the episodes of high concentration of PM10 $\left(>100 \mu \mathrm{g} \cdot \mathrm{m}^{-3}\right)$ may be noticeable: on Feb $11^{\text {th }}, 18^{\text {th }}$ and $27^{\text {th }}$ in Krakow, on Mar $3^{\text {rd }}, 10^{\text {th }}, 13^{\text {th }}$ and $16^{\text {th }}$ in Bialka, on Dec $29^{\text {th }}$ and $30^{\text {th }}$ and Jan $5^{\text {th }}, 6^{\text {th }}$ and $9^{\text {th }}$ in Skawina. For each sampling period the aerosol prehistory was profiled by conducting 72-hours air masses backward trajectories at $24 \mathrm{~h}$ intervals at 20,500 and $1500 \mathrm{~m}$ a.s.1 (Figure 2). These backward trajectories enabled to identify the source of origin of aerosols during the above mentioned episodes of PM10 high concentrations. PM10 concentration in Krakow significantly increased on Feb $11^{\text {th }}$ and Feb $18^{\text {th }}$ and reached the maximum values equal to 100,0 and 128,4 $\mu \mathrm{g} \cdot \mathrm{m}^{-3}$, respectively. These values were reported when Krakow was under the influence of air masses moving from the southeast direction. As the local wind direction on these days was similar to the air mass advection (Figure 1), the origin of PM10 is influence by local sources. The backward trajectories computed for Feb $11^{\text {th }}$ and Feb $18^{\text {th }}$ showed that air masses moved very low, below the $500 \mathrm{~m}$ a.s.1., what together with low humidity $(76 \%)$, temperature $\left(0.4{ }^{\circ} \mathrm{C}\right)$ and wind speed $\left(1.7 \mathrm{~m} \cdot \mathrm{s}^{-1}\right)$ may point to occurrence of the temperature inversion. For most of the study period in Krakow the air masses trajectories moved on the height lower than $500 \mathrm{~m}$ a.s.l. with exemptions of Feb $8^{\text {th }}, 13^{\text {th }}$ and $24^{\text {th }}$. Krakow was then under the influence of west $\left(\mathrm{Feb} 8^{\text {th }}\right.$ and $\left.13^{\text {th }}\right)$ and southeast (Feb 24 $4^{\text {th }}$ ) air masses advection (Figure 2). These masses carried the middle-polluted by aerosols ambient air resulting in the PM10 concentrations on these days equal to: $44.3,64.9$ and $42.6 \mu \mathrm{g} \cdot \mathrm{m}^{-3}$. Similar relations were reported for Skawina when on Dec $31^{\text {st }}$ 2013 , Jan $4^{\text {th }}$ and $7^{\text {th }} 2014$ the PM10 concentration was accounted for $43.9,54.8$ and $70.4 \mu \mathrm{g} \cdot \mathrm{m}^{-3}$. On these day Skawina was under the influence of long-range air masses which moved at the height of $1000 \mathrm{~m}$ a.s.1. Therefore, the long-range transport of aerosols should be considered, beyond the local sources, as the second source of particulate matter in Krakow and Skawina. Especially that in Skawina the wind speed obtained up to $14 \mathrm{~m} \cdot \mathrm{s}^{-1}$. On the other hand in Krakow the highest concentrations of nitrates and sulfates $\left(3.6 \mu \mathrm{g} \cdot \mathrm{m}^{-3}\right.$ and 6.3 $\mu \mathrm{g} \cdot \mathrm{m}^{-3}$, respectively) were reported. This is especially seen in Krakow where the highest concentrations of nitrates and sulfates $\left(3.6 \mu \mathrm{g} \cdot \mathrm{m}^{-3}\right.$ and $6.3 \mu \mathrm{g} \cdot \mathrm{m}^{-3}$, respectively) were reported. Strong correlations between ions $\left(\mathrm{NO}_{3}{ }^{-} / \mathrm{SO}_{4}{ }^{2-}=0.67\right.$ and $\mathrm{NO}_{3}{ }^{-} / \mathrm{NH}_{4}^{+}=0.81$, Table 3$)$, additionally proves the origination of aerosols from the 
secondary sources. In Bialka the augmented concentrations of PM10 which occurred actually during the whole study period were probably the result of prevailing meteorological conditions. Low temperature foster the accumulation and condensation of particles suspended in the atmosphere. The wind velocity in Bialka was as low as in Krakow. As a consequence the pollutants could not be well dispersed.
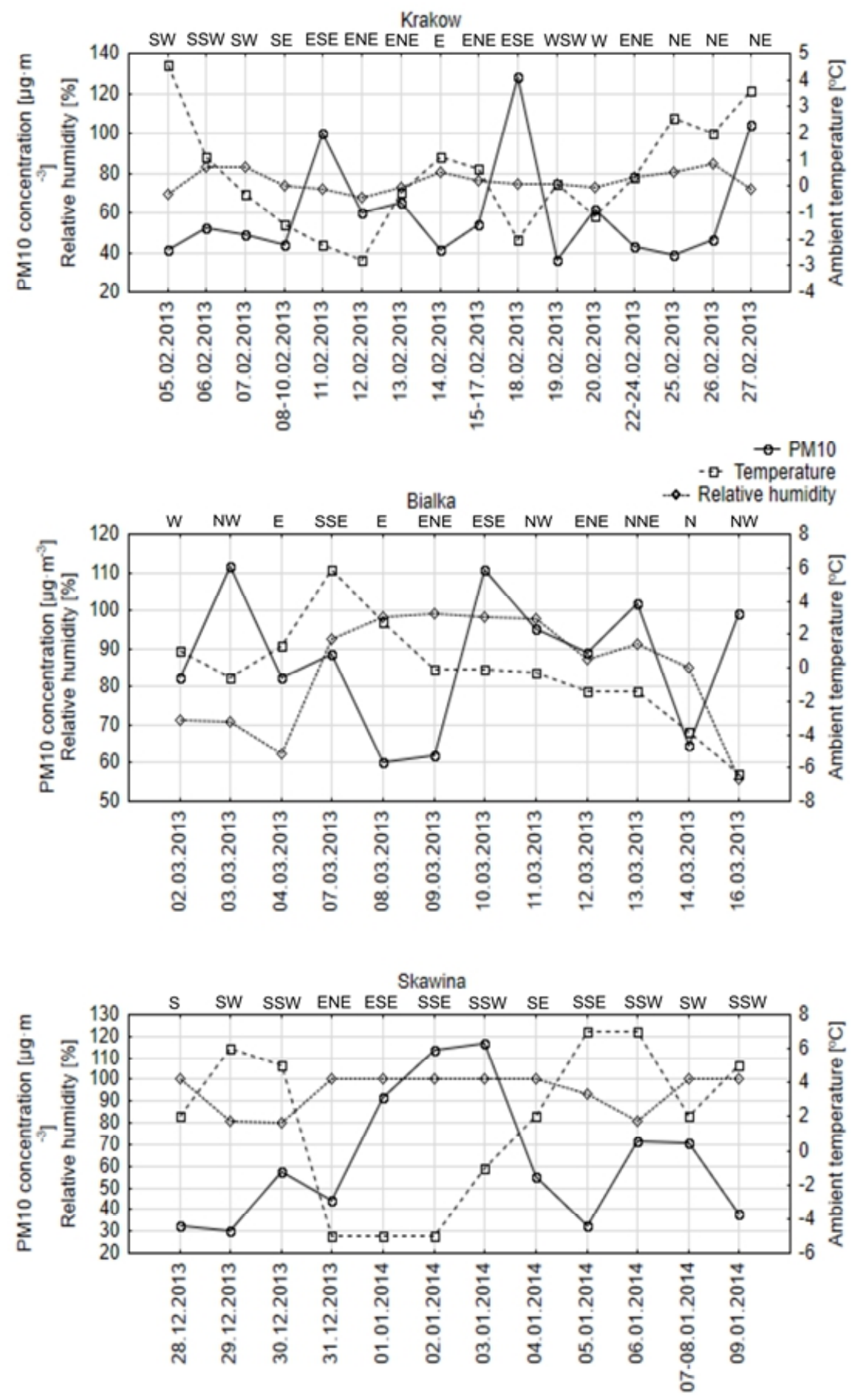

Figure 1. Variation of PM10 concentration at measuring stations during the study periods vs. meteorological conditions.

\subsection{Organic and elemental carbon in PM10}

The contribution of the total carbonaceous species (TC) into the PM10 mass was accounted to $32 \%$ in Krakow, $28 \%$ in Bialka and $74 \%$ in Skawina reaching the mean values of the TC concentration equal to $19.1 \pm 10.6$, $24.9 \pm 10.6$ and $46.5 \pm 20.4 \mu \mathrm{g} \cdot \mathrm{m}^{-3}$, respectively.
The highest contribution of carbonaceous species was observed in Skawina. However, this was affected by the presence of a specific emission source: in Skawina, samplers were placed near a factory which usually uses organic oils for manufacturing processes. The evaporation of these high temperature organic oils 
resulted in the increased contribution of carbonaceous species. According to the Didyk et al, 2000 study, the concentration of the TC concentration in highly polluted urbanized areas is suspected to be at the level of 85 $\mu \mathrm{g} \cdot \mathrm{m}^{-3}$, as it was investigated in Santiago (Chile) [11]. Significantly lower values were noted in the United Kingdom: $6.4 \pm 4.6 \mu \mathrm{g} \cdot \mathrm{m}^{-3}$ at the Bristol Road Site, $5.6 \pm 3.2 \mu \mathrm{g} \cdot \mathrm{m}^{-3}$ at the Birmingham city center site and $4.6 \pm 3.5 \mu \mathrm{g} \cdot \mathrm{m}^{-3}$ at the Churchill Pumping Station site. However, the TC fraction contributed in $24 \%$ at the Bristol Road Site, in $23 \%$ at the Birmingham city center

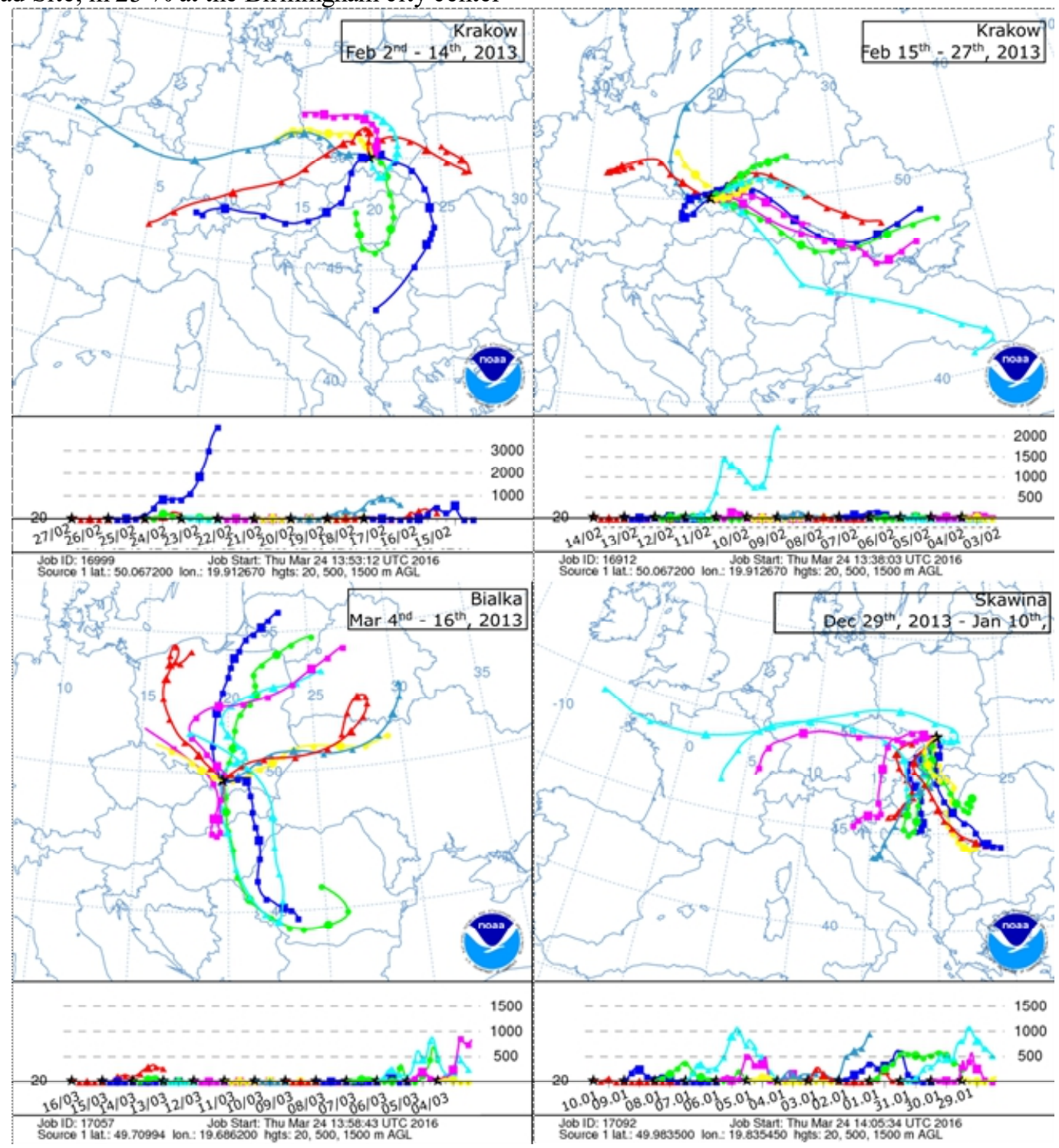

Figure 2. Backward trajectories computed for the whole study periods at three measuring stations in Krakow, Bialka and Skawina.

The mean concentration of elemental carbon was noted on the level of $3.9 \pm 2.8 \mu \mathrm{g} \cdot \mathrm{m}^{-3}$ in Krakow, $4.1 \pm 3.1$ $\mu \mathrm{g} \cdot \mathrm{m}^{-3}$ in Bialka and 9.6 $\pm 3.3 \mu \mathrm{g} \cdot \mathrm{m}^{-3}$ in Skawina (Table 2 ), contributing averagely in $6 \%, 5 \%$ and $18 \%$, respectively, into the PM10 mass fraction. The EC-to-TC ratio, which performs the origin of carbonaceous species from anthropogenic sources as the EC is a primary pollutant [14], was accounted for 0.19 in Krakow, 0.15 in Bialka and 0.23 in Skawina. The higher the ratio is, the stronger the environment is impacted by the local emission sources. The maximum value of the $\mathrm{EC} / \mathrm{TC}$ was observed on Feb $2^{\text {nd }}$ in Krakow $(0.32)$, on Mar $4^{\text {th }}$ site, and in $24 \%$ at the Churchill Pumping Station site [12]. Gdynia, in turns, is characterized by $5.5 \mu \mathrm{g} \cdot \mathrm{m}^{-3}$ of TC fraction and $29 \%$ of its contribution into the PM10 mass [8]. Unlike i.e. in South Pole, where the TC concentration was accounted for $0,0015 \mu \mathrm{g} \cdot \mathrm{m}^{-3}$ [13]. Krakow, Bialka and Skawina are more closed to the TC concentrations reported in Santiago. Moreover, the TC concentrations reported in three measuring locations were greater by six orders of magnitude than this one measured in South Pole. 
absorbed on the particulates surface. Because EC has a residence time of 6 days it could be transported hundreds or thousands kilometers from its source of origin [15].

Table 3. Spearman's rang correlation coefficients computed for carbonaceous species and measured constituents of the PM10 $(\mathrm{p}<0.05)$.

\begin{tabular}{|c|c|c|c|}
\hline Parameter & Krakow & Bialka & Skawina \\
\hline $\mathrm{OC}-\mathrm{PM} 10$ & 0.74 & - & 0.98 \\
\hline $\mathrm{OC}-\mathrm{EC}$ & 0.76 & 0.89 & - \\
\hline $\mathrm{OC}-\mathrm{Cl}^{-}$ & 0.68 & - & 0.59 \\
\hline $\mathrm{OC}-\mathrm{NO}_{3}^{-}$ & 0.52 & - & - \\
\hline $\mathrm{OC}-\mathrm{SO}_{4}^{2-}$ & - & - & - \\
\hline $\mathrm{OC}-\mathrm{Na}^{+}$ & 0.85 & - & 0.89 \\
\hline $\mathrm{OC}-\mathrm{NH}_{4}^{+}$ & 0.53 & - & 0.83 \\
\hline $\mathrm{OC}-\mathrm{K}^{+}$ & 0.63 & 0.94 & 0.68 \\
\hline $\mathrm{OC}-\mathrm{Mg}^{2+}$ & - & - & - \\
\hline $\mathrm{OC}-\mathrm{Ca}^{2+}$ & - & - & - \\
\hline $\mathrm{EC}-\mathrm{PM} 10$ & - & - & - \\
\hline $\mathrm{EC}-\mathrm{Cl}^{-}$ & 0.78 & 0.66 & - \\
\hline $\mathrm{EC}-\mathrm{NO}_{3}^{-}$ & - & - & - \\
\hline $\mathrm{EC}-\mathrm{SO}_{4}{ }^{2-}$ & - & - & - \\
\hline $\mathrm{EC}-\mathrm{Na}^{+}$ & 0.72 & 0.73 & 0.59 \\
\hline $\mathrm{EC}-\mathrm{NH}_{4}^{+}$ & - & - & - \\
\hline $\mathrm{EC}-\mathrm{K}^{+}$ & - & 0.89 & - \\
\hline $\mathrm{EC}-\mathrm{Mg}^{2+}$ & 0.62 & 0.60 & - \\
\hline $\mathrm{EC}-\mathrm{Ca}^{2+}$ & - & 0.64 & - \\
\hline Ioc - relative humidity & -0.65 & $(-0.53)$ & $(-0.45)$ \\
\hline $\mathrm{I}_{\mathrm{EC}}-$ relative humidity & $(-0.29)$ & $(-0.56)$ & -0.73 \\
\hline IOC - wind speed & - & 0.57 & 0.86 \\
\hline $\mathrm{I}_{\mathrm{EC}}-$ wind speed & - & 0.72 & 0.84 \\
\hline
\end{tabular}

While transporting the particulates over the lands, the organic compounds could be transformed undergoing photochemical processes or gas-to-particles conversion [16] resulting in the increased contribution of organic carbon into the total carbon fraction: $81 \%$ in Krakow, $92 \%$ in Bialka and $87 \%$ in Skawina on Feb $2^{\text {nd }}$, Mar $13^{\text {th }}$ and Jan $7^{\text {th }}-8^{\text {th }}$, respectively. The mean concentration of the organic carbon was equal to $15.2 \pm 8.0 \mu \mathrm{g} \cdot \mathrm{m}^{-3}$ in Krakow, 20.8 $\pm 8.3 \mu \mathrm{g} \cdot \mathrm{m}^{-3}$ in Bialka and $36.9 \pm 19.1$ $\mu \mathrm{g} \cdot \mathrm{m}^{-3}$ in Skawina ranging between 7.3 and $35.0 \mu \mathrm{g} \cdot \mathrm{m}^{-3}$, 7.4 and $31.8 \mu \mathrm{g} \cdot \mathrm{m}^{-3}, 13.2$ and $74.8 \mu \mathrm{g} \cdot \mathrm{m}^{-3}$, respectively (Table 2). Significant correlation between organic carbon and PM10 was observed for Krakow (0.74) and Skawina (0.98) pointing out that OC originated from the same source as PM10 (Table 3). Therefore, in Skawina the highest concentrations of $\mathrm{Cl}^{-}$and $\mathrm{K}^{+}\left(3.7 \mu \mathrm{g} \cdot \mathrm{m}^{-3}\right.$ and 0.6 $\mu \mathrm{g} \cdot \mathrm{m}^{-3}$, respectively, Table 2 ) suggested that, beyond the manufacturing processes near the study location, aerosols have an origin in coal and biomass combustion. In Bialka the occurrence of aerosols was probably influenced by the presence of several emission sources: a. biomass combustion as the Spearman's rang correlation coefficient for $\mathrm{OC} / \mathrm{K}^{+}$and $\mathrm{EC} / \mathrm{K}^{+}$reached the high values of 0.94 and 0.89 , respectively; potassium ions are mainly emitted during the biomass combustion [17]; b. coal combustion as EC was correlated with $\mathrm{Cl}^{-}[18]$ in $66 \%$ and with $\mathrm{Na}^{+}$[19] in $73 \%$. In Krakow, besides the coal combustion, the ambient pollution was affected during the study period by photochemical processes leading to creation of secondary aerosols. This is confirmed by significant correlation between $\mathrm{OC}$ and $\mathrm{NO}_{3}^{-}(0.52)$ and $\mathrm{NH}_{4}{ }^{+}(0.53)$. Nitrate ions are created during the secondary reactions with the gas precursor $\mathrm{NO}_{\mathrm{x}}$ in the atmosphere [2]. Moreover, nitrates are emitted from Diesel engine exhausts and during combustion processes, mainly for houses-heating purposes. In winter time the phenomenon is especially noticeable as nitrate ions exhibit a stronger association to ammonium ions in urban areas than in rural regions [20]. In Krakow and Bialka the significant correlation between organic and elemental carbon was reported suggesting the common source of origin. The existence of different sources and processes generating various proportions of carbon is reflected by highly variable $\mathrm{OC} / \mathrm{EC}$ ratios [7,21]. In this study, the mean OC-to-EC ratio was accounted for $4.6(2.2-7.8)$ in Krakow, 6.4 (2.8 - 10.9) in Bialka and $4.0(0.8-6.7)$ in Skawina. Accordingly with considerations presented by Sillanpaa et al. 2005, a low OC/EC ratio can be associated with fresh traffic aerosol (2.2 and 0.8 for lightduty gasoline and heavy-duty diesel vehicles, respectively), whereas residential heating (wood combustion 4.15 and natural gas home appliances 12.7), forest fires (14.5) and dust from paved roads (13.1) show remarkably higher ratios [22]. Obtained OC/EC ratios for coarse particles in winter time points out that on measurement stations carbonaceous constituents had a complex origin [23].

\subsection{The flux of carbonaceous species dry deposition}

Atmospheric aerosols emitted to the atmosphere undergo various processes like transboundary transport, degradation or deposition on the ground. The deposition of particles is a very important process for atmosphere 
self-cleaning, which, in turn, influences aquatic environment pollution levels [24,25]. The average OC and EC dry deposition flux was accounted for 2.0 \pm 0.7 and $0.5 \pm 0.3 \mathrm{mg} \cdot \mathrm{m}^{-2} \cdot \mathrm{d}^{-1}$, respectively in Krakow, 2.6 \pm 1.9 and $0.6 \pm 0.5 \mathrm{mg} \cdot \mathrm{m}^{-2} \cdot \mathrm{d}^{-1}$, respectively in Bialka, $13.3 \pm 10.6$ and $3.7 \pm 2.9 \mathrm{mg} \cdot \mathrm{m}^{-2} \cdot \mathrm{d}^{-1}$, respectively in Skawina. The values of the dry deposition fluxes of carbonaceous species were calculated according to the formulas presented in the previous paper of Styszko et al, 2015 [26]. The values of EC fluxes were lower by one order of magnitude than OC fluxes at all measuring locations. The trend of OC deposition flux reflects the trend of EC deposition flux. Similarly, maximum and minimum values of the dry deposition flux reflect the variations in PM10 concentration. Skawina demonstrates the highest values of carbonaceous species dry deposition fluxes and is higher by one order of magnitude than Krakow and Bialka. In Skawina the widest range of OC and EC fluxes was observed which ranged from 2.3 to $31.6 \mathrm{mg} \cdot \mathrm{m}^{-2} \cdot \mathrm{d}^{-1}$ and from 0.8 to $8.3 \mathrm{mg} \cdot \mathrm{m}^{-2} \cdot \mathrm{d}^{-1}$, respectively. It was undoubtedly caused by the highest contribution of carbonaceous species into the PM10 mass fraction and the highest values of wind speed reported for this study period (Table 2).
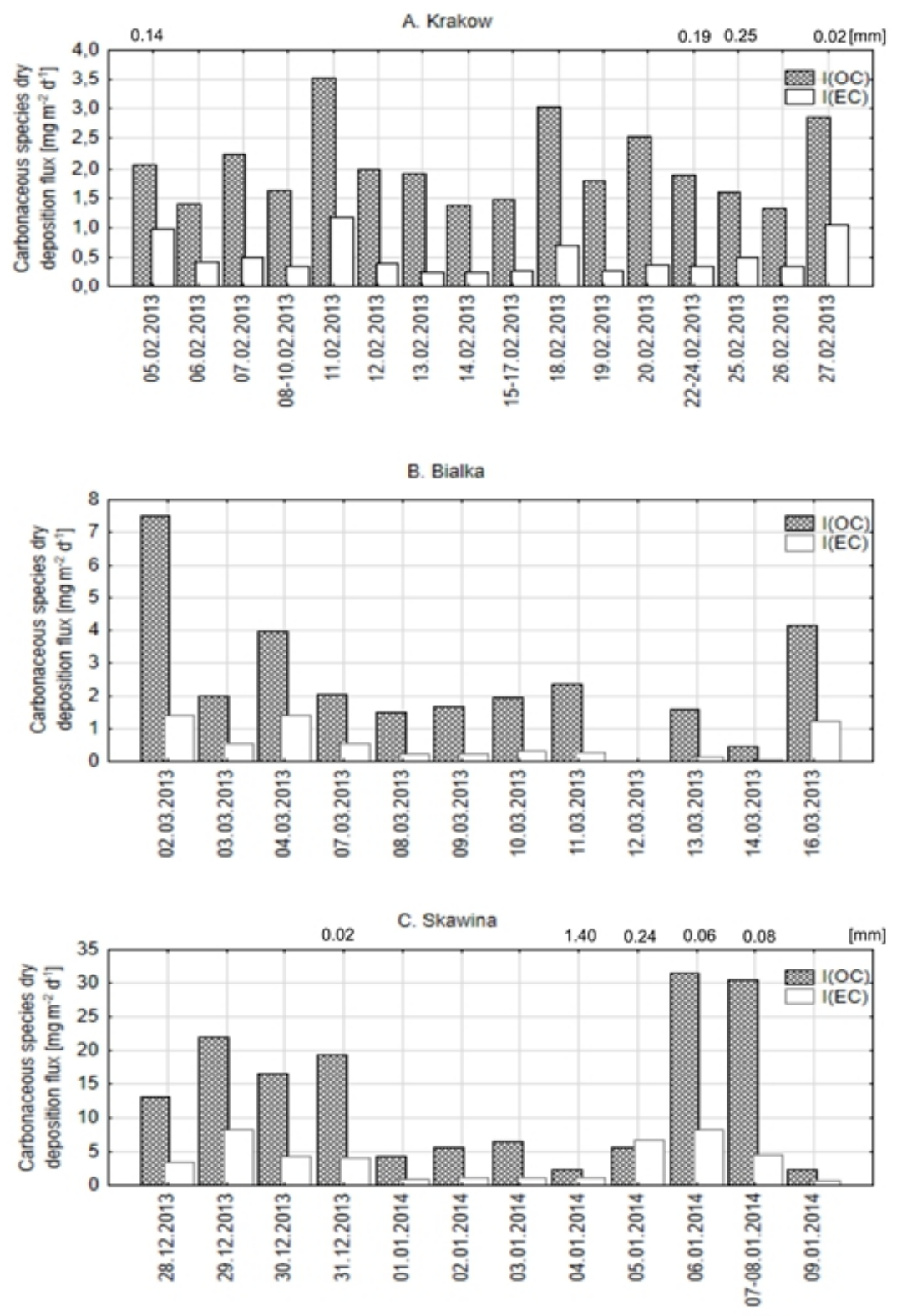

Figure 3. Daily variations of the OC and EC dry deposition flux $\left[\mathrm{mg} \cdot \mathrm{m}^{-2} \cdot \mathrm{d}^{-1}\right]$ with inclusion of rainy days $[\mathrm{mm}]$.

Figure 3 presents the daily variations of the $\mathrm{OC}$ and EC dry deposition fluxes in the measuring locations with the inclusion of the incineration amount. In Bialka no incineration was reported. After each rainy day in Krakow and Skawina, i.e. Feb $22^{\text {nd }}-25^{\text {th }}$ or Jan $4^{\text {th }}-$ $8^{\text {th }}$, the OC and EC dry deposition fluxes decreased. On these days when rain occurred, the particles were removed through the wet deposition. This is confirmed by the Spearman's rang correlation coefficients computed for $\mathrm{OC}$ and $\mathrm{EC}$ deposition fluxes and relative humidity (Table 3). The strongest correlation was observed in Krakow ( $\left.\mathrm{I}_{\mathrm{OC}}\right)$ and Skawina $\left(\mathrm{I}_{\mathrm{EC}}\right)$. The higher the relative humidity is, the lower contribution of the dry deposition into the particulates removal processes. Białka 
and Skawina additionally performed the relation between fluxes and wind velocity: the increase of the wind speed forces the increase of the dry deposition flux. In Bialka two significant increases of the carbonaceous species dry deposition fluxes were reported: on Mar $2^{\text {nd }}$ and Mar $16^{\text {th }}$. On these days, Bialka was under the influence of the west and northwest air masses moving on the low altitudes. Additionally, low relative humidity and ambient temperature below $0{ }^{\circ} \mathrm{C}$ caused the increase of the concentration of carbonaceous species. Augmented values of OC-to-EC ratios (5.3 and 3.4, respectively) refer to the origin of organic carbon from photochemical processes. In Skawina, at the beginning of the study period (Dec $28^{\text {th }}$ to $31^{\text {st }}$ ) the increased values of the Ioc were obtained. In this period the ambient temperature was below $0{ }^{\circ} \mathrm{C}$ what was favorable for aggregation of organic compounds and their absorption onto the particulates surface. At the end of the study period (Jan $6^{\text {th }}$ to $\left.8^{\text {th }}\right)$ Skawina was under the influence of long-range air masses moving from southwest direction. While transporting the organic species underwent many processes resulting in creation of secondary organic aerosols.

\section{Conclusions}

The mean concentrations of elemental particulate carbon ranged from $3.9 \mu \mathrm{g} \cdot \mathrm{m}^{-3}$ at the city center to $9.6 \mu \mathrm{g} \cdot \mathrm{m}^{-3}$ at the residential/industrial site. The mean concentrations of organic particulate carbon ranged from $15.2 \mu \mathrm{g} \cdot \mathrm{m}^{-3}$ at the city center site and $36.9 \mu \mathrm{g} \cdot \mathrm{m}^{-3}$ at the residential/industrial site. The highest correlation between OC and PM10 was observed at the residential/industrial area suggesting the origin of both from the same emission source. The strong correlation between EC and potassium ions and between EC and sodium and chloride ions proves the origination of carbonaceous species from biomass and coal combustion, respectively. This was especially visible in rural site. City center site was additionally influenced by long-range air masses carrying secondary organic aerosols. It was the consequence of emission from Diesel engines and accumulation of pollution during the temperature inversion occurrence. Deposition is the significant process in self-cleaning of the atmosphere. Low humidity, the lack of incinerations and high wind velocities favored the removal of particles through the dry deposition process.

\section{Acknowledgements}

This work was financed by AGH University Grant no 11.11.210.244. The authors acknowledge the financial support of OeaD and of the Ministry of Science and Higher Education (Poland) in the frame of project WTZ (WissenschaftlichTechnische Zusammenarbeit), No. PL09/2015.

\section{References}

1. X. Querol, A. Alastuey, C.R. Ruiz, B. Artiñano, H.C. Hansson, R.M. Harrison, E. Buringh, H.M. ten Brink, M. Lutz, P. Bruckmann, P. Straehl, J. Schneider, Atmos. Environ. 38,38 (2004).

2. B.H. Baek, V.P. Aneja, Q. Tong, Environ Pollut 129,1 (2004).
3. G. Peng, H. Puxbaum, H. Bauer, N. Jankowski, Y. Shi, Journal of Environmental Sciences 22,4 (2010).

4. G.-L. Shi, Y.-Z. Tian, Y.-F. Zhang, W.-Y. Ye, X. Li, X.-X. Tie, Y.-C. Feng, T. Zhu, Atmos. Environ. 45,32 (2011).

5. C. Hung-Lung, H. Yao-Sheng, Atmos. Environ. 43,26 (2009).

6. M.E. Birch, R.A. Cary, Analyst 121,9 (1996).

7. F. Mirante, P. Salvador, C. Pio, C. Alves, B. Artiñano, A. Caseiro, M.A. Revuelta, Atmospheric Research 138,0 (2014).

8. A. Lewandowska, L. Falkowska, D. Murawiec, D. Pryputniewicz, D. Burska, M. Bełdowska, Sci. Total Environ. 408,20 (2010).

9. H. Puxbaum, B. Gomiscek, M. Kalina, H. Bauer, A. Salam, S. Stopper, O. Preining, H. Hauck, Atmos. Environ. 38,24 (2004).

10. R.R. Draxler, G.D. Rolph, NOAA Air Resources Laboratory, College Park, MD.

11. B.M. Didyk, B.R.T. Simoneit, L. Alvaro Pezoa, M. Luis Riveros, A. Anselmo Flores, Atmos. Environ. 34,8 (2000).

12. J. Yin, R.M. Harrison, Atmos. Environ. 42,5 (2008).

13. A.D.A. Hansen, B.A. Bodhaine, E.G. Dutton, R.C. Schnell, Geophys. Res. Lett. 15,11 (1988).

14. A.M. Jones, R.M. Harrison, Atmos. Environ. 39,37 (2005).

15. L. Husain, V.A. Dutkiewicz, A.J. Khan, B.M. Ghauri, Atmos. Environ. 41,32 (2007).

16. J.H. Seinfeld, S.N. Pandis, Atmospheric chemistry and physics: from air pollution to climate change, (John Wiley \& Sons, 1986).

17. C. Schmidl, I.L. Marr, A. Caseiro, P. Kotianová, A. Berner, H. Bauer, A. Kasper-Giebl, H. Puxbaum, Atmos. Environ. 42,1 (2008).

18. A. McCulloch, M.L. Aucott, C.M. Benkovitz, T.E. Graedel, G. Kleiman, P.M. Midgley, Y.-F. Li, Journal of Geophysical Research: Atmospheres 104,D7 (1999).

19. S.S. Kim, Y.S. Kang, H.D. Lee, J.K. Kim, S.C. Hong, Journal of Industrial and Engineering Chemistry 18,6 (2012).

20. W. Zhao, P.K. Hopke, L. Zhou, Atmos. Environ. 41,9 (2007).

21. K. Styszko, M. Kistler, K. Szramowiat, M. Nowak, A. Kasper-Giebl,(to be published).

22. M. Sillanpää, A. Frey, R. Hillamo, A.S. Pennanen, R.O. Salonen, Atmos. Chem. Phys. 5,11 (2005).

23. M. Viana, X. Chi, W. Maenhaut, X. Querol, A. Alastuey, P. Mikuška, Z. Večeřa, Atmos. Environ. 40,12 (2006).

24. S.A. Slinn, W.G.N. Slinn, Atmos. Environ. 14,9 (1980).

25. M.L. Wesely, B.B. Hicks, Atmos. Environ. 34,12-14 (2000).

26. K. Styszko, K. Szramowiat, M. Kistler, A. Kasper-Giebl, L. Samek, L. Furman, J.M. Pacyna, J. Gołaś, Comptes Rendus Chimie 2015). 